\title{
Revitalization of Learning Chemistry Based on Malay Culture to Establish the Education Character in Kepulauan Riau Province
}

\author{
Nancy Willian \\ Universitas Maritim Raja Ali Haji, \\ Kota Tanjungpinang, Kepulauan Riau \\ ncy_we@yahoo.co.id
}

\begin{abstract}
Conventional learning makes students tend to be passive in the classroom. On the other hand, the Malay society culture which is the identity and the characteristics of Kepulauan Riau Province is necessary to be integrated into teaching chemistry to achieve the aspired character education leading towards gold Indonesia 2045. The Values of Malay culture and characteristic of unique local culture like Kepulauan Riau Province, Pantun, Puisi, and syair, create an interactive learning, it's colliding cognitive and soft skills of students. Through the revitalization and intervention of cultural uniqueness and chemistry learning, this kind of learning needs to be studied further. This paper will describe the form of the revitalization of chemical-based learning by using Malay culture to establish character education in Kepulauan Riau Province
\end{abstract}

Keywords: Learning, chemistry, Syair, Pantun, Gurindam 12

\section{INTRODUCTION}

Education can be the starting point to solve the nation's problems. Especially for the problems originating from the destruction of Indonesian national character due to the pressures of globalization, development of information and technology. The number of cases demoralized today shows not meeting the educational goals in an effort to make human morality (character). The failure is suspected that the teaching that is held has not reached the level of character. Learning that is oriented on cognitive, skill and intellect lead to moral knowledge gaps (cognition) and behavior (action) being offset by the establishment mentality. This reinforces the reason, the need for revitalization of character education

On the other hand, only has meaning character education rooted in the culture where the value of the constructed value. The construction value of the character based on the local moral values which are based on local culture. Development of character-based education and culture should be a national program. The character values that are grown in the national program as outlined in the identity and character of learners of which is the value of honesty, trustworthy, solidarity, tolerance, responsibility, and caring of others [1].

Local Wisdom is the accumulation of knowledge and policies that grow and thrive in a community perspective theological, cosmological and sociological. There are several terms that are used interchangeably in defining local knowledge, for example, local knowledge, local culture, local advantages, the indigenous culture [2].

On the other hand, the idea of educational development based on local wisdom grounded in the belief that every community has specific strategies and techniques. Required values-based education to develop moral qualities, personality, the attitude of togetherness that is eroded by the times. Local genius is selected local advantages that are difficult to imitate, to foster identity, pride, and the potential for the advancement of society [3].

Improving the quality of human resources through education should be a good and purposeful. The task of carrying out education is a very complex business that involves a lot of elements and components. To obtain a quality education requires efforts to improve the implementation of good teaching and learning process supported by all components. As well as learning a complex science, especially chemistry requires creative and innovative efforts in improving the ability of learners. Kepulauan Riau Province bordering on Singapore. This makes the impact of globalization and technological progress is growing very rapidly. The province is known as the Malay culture with a strong tradition, character and Budi Pekerti (Manner)s. Various types of a culture deeply rooted in the Malay community life is one of the Malay literary works are Gurindam 12 filled with meaning and character and be able to produce character education. There is also the syair, pantun, and puisi. Local knowledge as the basis of character education is not adequate just a concept only but must be integrated and internalization of education, from learning objectives, curriculum, subjects/courses, approaches and instructional media. The concept is similar to that institution as a research center needs to seek a change in earnest character-based education and culture. Character and culture that developed in the school must be harmonized with the character and culture of the local, regional, and national levels. To that end, character education and culture needs to be developed based on local wisdom [4].

The success of the process of learning science at school is influenced by the cultural background which is owned by the students or the community where the school is located, in line with the stretcher, in addition to grounding philosophical, psychology, science and technology, socio-cultural foundation should be considered in the development of curriculum for 
education must contain the value in accordance with the prevailing values in society [5].

Learning approaches that raise the culture and local wisdom to serve as an object of learning science. This learning is directed at an organized learning that is tied to certain natural phenomena and events will add interest and student learning outcomes [6]. In addition, containing travel learning projects local knowledge, communicative language teaching (CLT) or learn the communicative language (CLL), increased awareness or generate a love of local culture [7].

\section{Urgency of Local Culture-Based Learning}

Providing education based local genius, local wisdom and knowledge indigenous are integrated into the form of educational objectives, subjects, approaches, media and teaching materials will provide the characteristics and advantages of the graduates. It also will be the hallmark and excellence of the institution, and will ultimately contribute to the excellence of the nation to achieve the golden generation of Indonesia in 2045 and virtuous character. More local culturebased learning can be enhanced by the choice of theme-oriented research on the development and empowerment of local potential asset. Research-based local genius is one strategy in order to address the nation's problems.

The view that the revitalization of the Malay cultural wisdom now and will come as a result of the very rapid growth of science and technology. Implications of globalization are more likely to take pride in the value - the value of western civilization. Malay culture into inspiration to build civilization, so will is able to build the world civilization progress of communication, information, and new age economy, changing aspects of life quickly. The tendency of the value of tradition became more widespread when the environment provides support. Species systems as a hallmark tradition of customary structures is no longer a basic reference in the act. Lack of empowerment of indigenous peoples in maintaining its presence poses a serious threat to traditional values next relay [8].

Malay culture is one that is relatively old culture. Distribution and influence cover the area between the islands of Madagascar-Miami west side to the south of New Zealand. Therefore, the position of Malays in Indonesia has become very important and become one of the major cultures that contribute to the development of national culture Indonesia

On the other hand, literature began to develop in the Kepulauan Riau Provinces, known as the Malay literature and culture. Learners are very familiar with and accustomed to classical literature they often encountered in public life, such as syair, pantun, gurindam, and puisi. Literature flourished in the Kepulauan Riau Provinces region well, which is also the birthplace area writer Raja Ali Haji are produce Gurindam 12

\section{DISCUSSION}

\section{A. Chemical-based learning discourse of Malay Culture}

The golden generation of 2045 is the effort made to realize the dream of the nation of Indonesia, namely the rise of the golden generation that is able to provide the goodness and greatness of Indonesia and delivery of quality learners in accordance with national educational goals set forth in Undang -undang Sistem Pendidikan Nasional N0. 20 Tahun 2013, which reads "The national education aims at developing students' potentials in order to become a man of faith and fear of God, noble, healthy, faithful, skilled, creative, independent, and become citizens of a democratic and responsible accountable."

Learning chemistry does not only emphasize the cognitive abilities but also giving out the opportunity for students to think creatively. Creating interactive learning atmosphere, a blend of literature such as puisi, Gurindam, pantun, and puisi. Interventions form of literature in chemistry learning make learning more attractive and improve the soft skills of the students [9]. Model thematic learning the nuances of local wisdom is able to increase the interest and student learning outcomes [10] and also can generate device-based guided inquiry learning culture through the analysis of the relevance of the local culture with chemical materials [11].

Several previous studies have been conducted in the science of science to collaborate with some of the works of art and literature. Implementation of project-based learning and culture, studying chemistry by making a play or puppet (wayang) play proved to increase the creativity of chemistry learning [12], [13]. Besides combining science and literature in improving student achievement through media stories chemistry (cerpen Kimia). Development of learning models, learning materials with the relevance of learning chemistry with local advantages in the form of natural resources, my source of human, social and cultural [14]. Besides local wisdom-based learning laboratories have also been developed with the well [15].

One of the breakthroughs in learning-based culture in the Kepulauan Riau Provinces is physics in the pantun, which is an innovative work in the field of education is beneficial especially useful for learners, educators and those who read it. Works made this makes the reader interested and provide great benefits for education both locally, nationally and internationally. With the learning such a big influence on the pantun that are characteristic of the Kepulauan Riau Provinces [16].

The above approach cultural make learners as a "weapon" in the face of learning science, especially chemistry. Based on some of the above presentation, the pair rests on the cognitive learning, and collaborate between social science and culture to be interesting to be produced. The learning process is created leading to Ethno pedagogic.

Their concept of learning science through multicultural it is expected that students and teachers can associate with the local cultural environment. In implementing the learning, the teacher is not only to convey in theory but also the transferable value of what was taken from the learning activities through character education. With the concept of the integrated science teaching to local culture can grow the value of the character as the character development of young generation in the Kepulauan Riau Provinces. It is given a lot of great scientists but no character values making prowess to do anything that can harm others. Through this learning, the students are able to become the young generation in the Kepulauan Riau Provinces are not 
only high but also with the intellectual refinement and can be one of the regions contribute to the young generation to the Indonesian character of gold in 2045.

Refinement of the Malay culture terrace beside the main reference heirs that are needed in life. Furthermore, in the Malay cultural revitalization in 2008, states that the Malay cultural values must be at internalizing haughty and useful by the younger generation in a sustainable Budi Pekerti ( Manner) in this case the role of institutions both formal and informal education is crucial. Works of Malay cultural peak like syair, pantun, and Gurindam should be a compulsory subject in the local curriculum wither. Because the contains the value of the Malay culture that promotes refinement, truth, reason and creative thinking. Associated with the teachers must also have the ability of competent so that the Malay lessons interesting by learners of various levels of education, in addition to the required textbooks, reading media and teaching media are inadequate, both in quality and quantity [17].

Kepulauan Riau Provinces are rich in ancient Malay literature. Some literature has become a national identity wither as the most famous Gurindam 12, syair, pantun, and puisi. There was also a Seloka, bidal or peribahasa, talibun and karmina. Malay literary have been rooted in people's self Kepulauan Riau Provinces.

Gurindam is Pantun of their association with the nation of the ancient Hindu nation. Usually, a two-line pantun that contains advice and counsel. Kepulauan Riau Province 12 is an old Malay literature, who was born in Tanjungpinang Kepulauan Riau Provinces, Raja Ali Haji. Kepulauan Riau Province 12 contains advice and instructions of life, noble character, which is one of the efforts to build the nation through character education. Character education is education that is oriented to the appreciation and experience of heritage.

One of the cultural heritage that has noble values is to build national character by Gurindam 12 . It has a depth of meaning character, the message, the beauty of the language that can be practiced in everyday life. This kind of character education will produce results. Intensively studying and practicing will be a bridge to reach the national character building process. Character education aspects contained in couplets 12 is aqidah, ibadah and morality. The third component is an essential component in building the character of the nation [18].

Gurindam 12 consist of 12 Pasal. Value of character education. As an example. The first and second chapter (pasal) of Ibadah and aqidah like the first chapter: "barang siapa yang tiak memegang agama, sekali-kali tidak boleh dibilang nama". In the words of the obvious meaning that doing good deeds, contrary to the religion will undermine the dignity and good name. Further teaching of morals and Budi Pekerti (Manner)s that are in chapter three to twelve, the importance of morals in my family, society and moral leadership. Besides maintaining the senses of misconduct that are in chapter 3. Furthermore, the fourth chapter explains how to keep the heart. Article sixth to eighth describes procedures for associating Budi Pekerti (Manner)s to friends, teachers. It is very closely related to the character in character education. Article ten, Raja Ali Haji explained about the character (adab) against manusia. Maka in reading, understanding the content couplets 12 , then the reader will interpret the message contained in the pantun level.

Pantun is a form of long puisi were very widely known. Pantun with a particular pattern. All forms of puisi consisting of two parts, namely the sampiran and part of the contents. Sampiran is the first two lines, and two subsequent Bagis is the content, goals, and objectives that will be presented in the pantun. Submission pantun usually contains advice and messages to be delivered. Malay community is very familiar with the pantun, several other activities and events are interspersed with puisi readings. Syair and a culture deeply rooted in daily life Malay community. Values and advisory message contains the character values that can be integrated into learning Collaboration and integration of value - the value of puisi in the learning of science, especially chemistry on the topic of chemical elements, have been able to increase interest, and student learning outcomes in Tanjungpinang [19].

In addition, there are literary of puisi or puisi, is a form of literary performance bound form of composition that emphasizes the sajal. Usually, consists of 4 lines and rhythmic AAAA, the fourth line contains a meaning and a poet. Just like couplets 12 , syair and pantun into an ancient culture that has become the joint aspects of community life wither. Forms of integration in learning puisi ever do in teaching physics

\section{B. Chemistry Base On Character of Local Wisdom}

Current conditions, we experienced a cultural degradation. Progress in the text no longer positively correlated, even inversely proportional to the high society politeness. The fact mentions the value of modesty and character has been lost, especially in education. Now the society has lost its character because it is not familiar with tub ancestral culture is loaded with the first value of local wisdom as forming the character of the nation. The need for character education in restoring the condition of the nation, laden with local knowledge, specific blood cultures. Ref. [20] in research mentions, through learning-download-upload bases, carried out in instilling the values of local wisdom in Markowitz character of the younger generation, intelligent IQ, EQ and SQ morals and noble character. Various grades refinement became the foundation of the envisioned character education in the world of Indonesian education.

Refinement, in every society, the mind becomes a very important element, the people said to be good and high understanding if the community has a refinement that is reflected in community activities. In accordance with the values of Islamic culture, refinement associated with thoughts, feelings actualized in words, statement, personality traits, attitudes, behavior, and temperament of human actions. Fineness as a symbol of goodness, always juxtaposed with the mind where Raja Ali Haji regards as the crucial character, which indicates the identity of Malay Islam. Kepulauan Riau Province 12 is one among the world's great works, of Raja Ali Haji. Kepulauan Riau Province is a literary work that utilizes the science of religion (Islam) and Malay philosophy as the foundation [21].

The character value is in character education consists of 18 types, among others: religious, honesty, tolerance, discipline, 
hard work, creative, independent, democratic, curiosity, the spirit of nationalism, love of country, respect for the achievements, communicative, love peace, likes to read, care for the environment, social care and responsibility. The value of the value will be integrated into the learning of local wisdombased chemistry Gurindam 12, Pantun and puisi.

Science learning model based on local wisdom can be done through the reconstruction of the original science (The indigenous science) into western science or scientific science. Application of science learning model based on local wisdom by performing observation of a culture in the community for the next reconstructed scientific concepts that ultimately was able to grow the character values of learners [22].

Revitalization if chemistry learning base in Malay, such as:

\section{Gurindam 12 Karya Raja Ali Haji}

Learning chemical forms of integration with the approach of the Malay culture, Kepulauan Riau Provinces seen from the example of Chemistry couplets 12 below. In chemistry learning, learners will interpret the contents of the Gurindam 12 of Raja Ali Haji, section 1-2 provides the meaning of the values of the characters noble character, then on the 3-4 line is replaced with a chemical substance

\section{Pasal Yang Pertama}

Jangan lah dibawa jiwa yang merana
Karena tiada hakekat yang berguna

Reaksi kimia akan bermakna

Bila berlangsung dalam laju yang bermakna pula

\section{Pasal Yang Kedue}

Jika hendak menurunkan tensi, perbanyaklah amal ke segala sisi

Jika hendak Menurunkan Energi aktivasi berakibat pula menaikan laju reaksi

Bila kita berendah hati menandakan pribadi yang mantap

Sehingga perubahan energy pun menjadi tetap

\section{Pasal Yang Ketige}

Jika kita mengenal yang empat

Tahu lah kite empat faktor penyebab

Konsentrasi, katalis, temperature dan luas permukaan Adalah empat factor penyebab laju reaksi yang tepat

\section{Pasal Yang Keempat}

Barang siape banyak merase itulah tanda hidup lama dijalani

Barang siape tahu laju reaksi maka taulah dia banyaknya variasi

TABEL I. RECONSTRUCTION OF CHEMISTRY LEARNING CHEMISTRY AS CHARACTER EDUCATION IN KEPULAUAN RIAU PROVINCE AS TOPIC ORGANIC CHEMISTRY

\begin{tabular}{|c|c|c|c|}
\hline Pasal & Kepulauan Riau Province 12 & Character value & Organis Chemistry \\
\hline \multirow[t]{2}{*}{1} & Barang siapa mengenal dunia & \multirow{2}{*}{ Religius, tanggung jawab, } & Barang siapa tahu penamaan alkohol \\
\hline & Tahulah ia barang yang terpedaya & & Akhiran ana diganti dengan anol \\
\hline \multirow{2}{*}{2} & Barang siapa mengenal yang tersebut & \multirow{2}{*}{ Religius, jujur, disiplin } & Barang siapa mengenal gugus alkil \\
\hline & Tahulah ia makna takut & & Tahulah $i a-a n a$ diganti $-i l$ \\
\hline \multirow[t]{2}{*}{3} & Apabila terpeliharakan mata & \multirow[b]{2}{*}{ Religius, cinta damai } & Apabila digunakan formaldehid \\
\hline & Sedikitlah cita-cita & & Itulah senyawa aldehid \\
\hline \multirow[t]{2}{*}{4} & Hati itu kerajaan dalam tubuh & \multirow{2}{*}{$\begin{array}{l}\text { Kreatif, peduli sosial, peduli } \\
\text { lingkungan, toleransi, }\end{array}$} & Pengolahan sabun didalam asam palmitat \\
\hline & Jikalau zalim segala anggota pun roboh & & Senyawa penting dalam asam karboksilat \\
\hline \multirow[t]{2}{*}{5} & Jika hendak mengenal orang yang berilmu & \multirow[b]{2}{*}{$\begin{array}{l}\text { Rasa ingin tahu, religious, } \\
\text { menghargai prestasi }\end{array}$} & Jika hendak mengenal menguji alkena \\
\hline & Belajar dan bertanya tiadalah jemu & & Reaksi bayer yang kita guna \\
\hline \multirow{2}{*}{6} & Cari olehmu akan sahabat & \multirow[b]{2}{*}{$\begin{array}{l}\text { Toleransi, peduli sosial, } \\
\text { komunikatif }\end{array}$} & Digunakan pelarut etanol \\
\hline & Yang boleh dijadikan obat & & Senyawanya dari alkohol \\
\hline \multirow[t]{2}{*}{7} & Apabila banyak berkata-kata & \multirow{2}{*}{ Jujur, religius } & Apabila terdengar oktil asetat \\
\hline & Disitulah jalan masuk dusta & & Aroma jeruk langsung diingat \\
\hline \multirow[t]{2}{*}{8} & Barang siapa khianat akan dirinya & \multirow[t]{2}{*}{ Jujur } & $\begin{array}{l}\text { Apabila terbentuk warna kuning dalam cincin } \\
\text { benzena }\end{array}$ \\
\hline & Apalagi kepada lainnya & & Reaksi xantoprotein yang kita guna \\
\hline \multirow{2}{*}{9} & Tahu perbuatan yang tak baik tetapi dikerjakan & \multirow{2}{*}{ Religius, kerja keras, mandiri } & Asam karboksilat isomer fungsi ester \\
\hline & Bukannya manusia yaitulah syaitan & & Alkohol isomer fungsinya eter \\
\hline \multirow{2}{*}{10} & Dengan bapak jangan durhaka & \multirow{2}{*}{ Religius, disiplin, jujur } & Apabila mengenal toluena \\
\hline & Supaya Allah tidak murka & & Bahan peledaklah kegunaannya \\
\hline \multirow{2}{*}{11} & Hendaklah berjasa & \multirow[b]{2}{*}{$\begin{array}{l}\text { Tanggungjawab, cinta tanah } \\
\text { air, semangat kebangsaan }\end{array}$} & Iodoform haloalkana \\
\hline & Kepada yang sebangsa & & Antiseptik yang diguna \\
\hline \multirow[t]{2}{*}{12} & Raja mufakat dengan menteri & \multirow{2}{*}{$\begin{array}{l}\text { Menghargai prestasi, } \\
\text { komunikatif, toleransi }\end{array}$} & Pelarut kloroform haloalkana \\
\hline & Seperti kebun berpagarkan duri & & Reaksi substitusi dari alkana \\
\hline
\end{tabular}


In Table I above, shows the original form of puisi Gurindam12 of Raja Ali Haji, which contains the character values and Budi Pekerti (Manner)s. In the Application of the learning process, students

will interpret the mandate and the value of advice on each article, will change it in the form of chemical gurindam. This allows inculcating character education to students, in addition to creating an atmosphere, interest, and innovation in chemical learning

Indonesia gold in 2045 defined the conditions state that intelligent, progressive, prosperous, modern, civil and character inhabited by a civilized society. The problems of education in Indonesia is not only limited to the intellectual quality of students is still low, but also a clear moral degradation occurs. Various cases of irregularities and violations of the law have affected much of education in Indonesia, such as violence and relationship which is based on a foreign culture. This, of course, resulted in moral behavior among students. Therefore, the concept of revitalization based learning Chemistry prepares young Malay culture in Kepulauan Riau Provinces to Indonesia in 2045 is not only the intellect but also the younger generation needs character

\section{a) Pantun}

A form of learning integration that the second chemical is Pantun. Pantun consists of sampiran and content (isi). In implemented chemistry learning syair, learners will make sampiran containing values and moral character education, while learning its contents contain chemical substances. Exemplified as follows:

Anak melayu suke bepanton

Panton di buat tidaklah lame

Tahukah kamu gunanya Kripton

Ialah untuk lampu reklame

Bukan kacang sembarang kacang

Kacang yang dibawa kacang atom

Energi ionisasi gas mulia akan berkurang

Pergi ke hutan melihat elang

Pulang ke rumah melihat sapi

KalsiumSulfatdihidrat membalut patah tulang

Senyawa Stronsium membuat kembang api

Hendak berkawan biar setia

Kesetiaan bukan sekedar kenal

Piramida trigonal ialah ammonia

Metana bagian dari tetrahedral

Gula di paket tolong di takar

Lekas dibawa ke took maya

SP2 ialah hibrid trigonal planar

Boron flourida ini contohnya b) Puisi

The third integration shape is puisi. In chemistry learning puisi, learners will be free to pour creative puisi with chemical content. As follows. The character values are shown in the following pantun:

\section{Ke-Muliaanku}

Aku merasa seakan sempurna dari mereka Memiliki kelebihan yang begitu luarbiasa Tak perlu siapapun membantuku Karena aku mampu berdiri sendiri Aku tidak perlu melepas atau menerima bantuan dari mereka

Aku juga tak mudah bereaksi dengan unsur lainnya Karena aku sangat sulit berinteraksi dengan apa saja Aku lebih mulia dari unsur apapun..

Maka aku dikenal dengan nama gas mulia..

Kemulianku terletak pada kestabilan yang aku miliki Aku juga terletak pada angka yang mengagumkan Terletak pada golongan VIIIA

In the process of chemical-based learning culture through, takes the role of teacher or education personnel has the same orientation in achieving learning success. In the learning activities, teachers develop a multicultural-oriented climate that emphasizes social justice and culture for students. In connection with that teachers need to transform themselves towards personal multicultural and has a design based multicultural learning that is not oriented to the cognitive alone [23]. Research conducted by [24] in a model-based science learning local culture to develop the potential of basic science showed that the development of culture-based science learning was found that $90 \%$ of teachers stated a desire to develop the model, but only $20 \%$ of teachers who have insight/knowledge and abilities to develop it. This indicates that the culture-based learning model was well received, although the insight and knowledge they still minimal. The lack of insight/knowledge of students towards science-based learning model culture lies in the ability of students to find examples of incident/event that contains the value of local knowledge to be integrated into the syllabus

Of the three forms of learning revitalization of the chemistry that leads to the local knowledge (Gurindam 12, syair and pantun) will grow, can be applied in everyday life, understood, practiced and the identity of the nation's future. So that character education is hoping to aspire to be achieved, but it is through this model approach will make learning more active, love their own culture, being responsible and independent corresponding expected the value of character education. 


\section{CONCLUSIONS}

Human development in the modernization of the current area, it takes part of education to prepare students to think critically, creatively, logically, the initiative in response to the environmental issues of the impact of the development of science society. Learning based on local wisdom, good natural resources, social and cultural believed to be one way to bridge the educational character of the envisioned establishment of nation

Thus, chemical science-oriented learning indigenous Malay culture (Gurindam 12, Pantun and Puisi) is able to generate an understanding of character education, noble character, single bhineka Ika.Utilizing cultural science as a personal culture of students in learning regarded as "entry behavior" learners so as to produce creative learning, innovative learning that is fun to prepare for the golden generation

\section{REFERENCES}

[1] Subamia, I Dwi Putu. 2011. "Optimalisasi Eksistensi Laboratorium Pendidikan Sebagai Wahana Strategis Revitalisasi Pendidikan Karakter Berlandaskan Kearifan Lokal." In Seminar Nasional FMIPA Undiska, Undiska, 223-36.

[2] Musanna, Al. 2011. "Rasionalitas Dan Aktualitas Kearifan Lokal Sebagai Basis Pendidikan Karakter.” Jurnal Pendidikan dan Kebudayaan 17(6): 588-98.

[3] Merdekawati, Krisna. 2012. Menumbuhkan Keunggulan Bangsa Melalui Pendidikan Kimia Berbasis Local Genius 1. Yogyakarta.

[4] Sutyitno, Imam. 2012. "The Development of Education on the Character and Culture of the Nation Based on the Local Wisdom." Jurnal Pendidikan Karakter 2(1): 1-13.

[5] Tandililing, Edy. 2011. "Pengembangan Ethnosains Dalam Pembelaajran Pendidikan Sains Di Sekolah." Universitas Pendidikan Indonesia. http://repository.upi.edu (April 12, 2017).

[6] Crsitian Damayanti, Novi ratna Dewi, Isa Akhlis. 2015. "Unnes Science Education Journal.” Unnes Science Education Journal 4(2): 274-81. http://journal.unnes.ac.id/sju/index.php/usej\%0APENGEMBANGAN.

[7] Sa-ngiamwibool, Amporn. 2012. "Raising Learner Awareness of Local Wisdom in Tour-Related Project Teaching." Indonesian Jornal of Applied Linguistics 1(2): 1-16.

[8] Wandansari. 2013. "Aktulialisasi Nilai-Nilai Tradisi Budaya Daerah Sebagai Kearifan Lokal Untuk Memantapkan Jatidiri Bangsa.”
[9] Willian, Nancy. 2014. "Pengembangan Kemampuan Mahasiswa Melalui Intervensi Sastra Dalam Pembelajaran Kimia.” Jurnal Zarah 2.

[10] Dewi, Ni Wayan, Budi Santika Kristiantari, M G Rini Negara, and I Gusti Agung Oka. 2014. "Model Tematik Bernuansa Kearifan Loka Berbantuan Media Animasi Berpengaruh Terhadap Hasil Belajar IPA Siswa Kelas III SD Negeri Gugus Kapten Japa." Mimbar Pgsd Universitas Ganesha 2(1).

[11] Suardana, I Nyoman. 2011. "Analisis Relevansi Budaya Lokal Dengan Materi Kimia SMA Untuk Mengembangkan Perangkat Pembelajaran Inkuiri Terbimbing Berbasis Budaya.” Jurnal Pendidikan Indonesia 3(1): 12-14.

[12] Ahkamajaya, Hada. 2011. Implementasi Pembelajaran Berbasis Proyek Dan Budaya:belajar Kimia Dengan Pembuatan Naskah Drama/lakon Wayang Orang. Yogyakarta.

[13] Mami, Ari. 2013. Efektivitas Penerapan Media Cerpen Kimia Pada Materi Teori Atom Mekanika Kuantum Terhadap Peningkatan Motivasi Dan Prestasi Belaajr Peserta Didik Kelas XI Semester 1 SMA N Purwodadi Tahun 2012/2013. Yogyakara.

[14] Hernani, Ahmad Mudzakir, heli Siti H. 2012. "Meningkatkan Relevansi Pembelajaran Kimia Melalui Pembelajaran Berbasis Kearifan Dan Keunggulan Lokal ( Suatu Studi Etnopedagogi Melalui Indigenous Material Chemistry)." Journal Pengajaran MIPA 17(1): 96-106.

[15] Wiratma, I Gusti Lanang, and I Wayan Subagia. 2015. "Pengelolaan Laboratorium Kimia Pada SMA NEGERI Di Kota Singaraja: (Acuan Pengembangan Model Panduan Pengelolaan Laboratorium Kimia Berbasis Kearifan Lokal Tri Sakti).” Jurnal Penelitian Indonesia 3(2): 425-36.

[16] Darson. 2012. Fisika Dalam Syair. ed. Tristanti. Yohyakarta Leutikaprio.

[17] Malik, Abdul. 2009. Memelihara Warisan Yang Agung. 1st ed. Yogyakarta: Akar Indonesia.

[18] Amin, Susanto Al. 2012. "Gurindam 12 Dan Rekonstruksi Karakter Bangsa.” Riau. http://riau.kemenag.go.id/artikel.

[19] Willian, Nancy, and Mini Andriani. 2015. "Pembelajaran Kimia Berbasis Kultur Budaya: Tinjauan Pembelaran Kimia Pantun Pada Topik Kimia Unsur." Zarah 3.

[20] Nugrahani, Farida. 2013. "Penanaman Nilai Kearifan Lokal Melalui Pembelajaran Unggah-Unggah Basa Dalam Upaya Pembentukan Karakter Generasi Muda.” In Proceeding Seminar Nasional Lembaga Kebudayaan Universitas Malang,

[21] Malik, Abdul. 2015. AKhlak Mulia: Tinjauan Sastra(dan)Agama. Batam: Rizki Fatir Cemerlang.

[22] Khusniati, Miranita. 2014. "Model Pembelajaran Sains Berbasis Kearifan." Indonesian Journal of Conservation 3(1): 67-74.

[23] Sudrajat. 2014. "Revitalization Of Multicultural Education." Jural Pembangunan Pendidikan : Pondasi dan Aplikasi 2(1): 82-90.

[24] Suastra, I Wayan. 1999. "Model Pembelajaran Sains Berbasis Budaya Lokal." Jurnal Pendidikan dan Pembelajaran 43(2): 8-16. 